\title{
DOES DEMOCRATIC INSTITUTIONS AND FOREIGN DIRECT INVESTMENT AFFECT ECONOMIC GROWTH? EVIDENCE FROM NIGERIA
}

\author{
Hassan O. Ozekhome \\ Department of Economics and Statistics, University of Benin, Benin City, Nigeria \\ hassanozeks1@gmail.com
}

\begin{abstract}
A reciprocally re-enforcing relationship exists between institutions, foreign direct investment and economic growth. Sound institutional framework which supports foreign direct investment is significant for driving rapid Economic growth. An important factor that has undermined rapid and sustained economic growth is the weak institutional structure, decrepit state capacity and low level of foreign direct investment in Nigeria. Democratic structures reflected in the rule of law, effectiveness and predictability of the judiciary and enforceability of contracts proceedings is imperative for accelerating economic growth. Employing the Generalized Method of Moments (GMM) estimation techniques on annual time series data covering the period from 1981 to 2015, the relationship between these variables was empirically investigated. The empirical findings reveal that democratic institutions and foreign direct investment are significant variables influencing economic growth in Nigeria. In particular, the results, using Nigerian data, show that weak institutions have a destabilizing impact on growth. The impact of FDI on the other hand is found to be positive and significant. Therefore, sound institutional framework, as well as appropriate and consistent macroeconomic policies that encourage foreign direct investment to propel rapid economic growth in Nigeria needs to be put in place.
\end{abstract}

Keywords: Democratic Institutions, Foreign direct investment, Economic growth, Nigeria GMM.

JEL Classification: F35, F43, O14, C13.

\section{Introduction}

The importance of democratic institutions and foreign investment for enhancing economic growth is well established and articulated in the growth literature. Sound investment policies are critical for rapid economic growth and on the other hand, aconducive institutional framework is indispensable for promoting sound policies investment (Avellanda, 2006; Diop, Dufrenot and Sanon, 2010). Thus, sound democratic institutions and investment are indispensable for propelling rapid economic growth. In particular, sound democratic structures in the context of the rule of law, effectiveness and predictability of the judiciary and the enforceability of contracts are critical for the stimulation of foreign investment and growth (Jensen, 2003; Fosu et al., 2006; Avellaneda, 2006, Diop et al, 2010).

A large body of theoretical and empirical determinants of economic growth in has shown that institutional framework is a deep determinant of growth. In particular, a large number of country-specific and cross-sectional studies have examined the determinants of growth (Barro 1998; Drazen, 2000 and Helpman 2004). Most of these studies have however been focused on the effects of physical and human capital accumulation, total factor productivity, technological innovation, the process of knowledge creation and diffusion, international trade and international economic as factors explaining growth empirics in different countries (Helpman 2004; Avellaneda, 2006, cited in Eregha, 2014). Empirical evidences have increasingly shown that strong democratic institutions and investment are indispensable to 
the growth process, as it could affect the incentives to accumulate, innovate and accommodate change (Kaufmann and Kraay, 2003, cited in Eregha, 2014). This position is supported by institutional development economists who argue that stable and sustained economic growth can only be guaranteed in the presence of sound institutional framework (Acemoglu et. al., 2002).

A growing number of literature stress that institutional structures which encompass the rule of law, political and economic equality, enforceability of contracts and secured property rights and foreign investment are significant to sustained economic growth and development (Kaufmann andKraay, 2000; Avellaneda, 2006). Many empirical studies have found a positive nexus between the quality of institutions as well as governance structures and economic growth (Acemoglu et al. 2002; Easterly and Levine 2002 and Rodrik, Subramanian and Trebbi, 2004; Diop et al. 2010). A broad harmony thus exist between growth and development experts as well as international policy-makers that good and quality institutions and sufficient investment are prerequisite for sustained economic growth (Kaufmann and Kraay, 2000; Knack, 2003). The earliest attempts to analyze economic and political determinants of growth were focused on the effect of political regimes on economic performance. Accordingly, studies analyzing whether democratic institutions promotes or impedes economic growth have produced three varying schools of thought (Feng 2003; Avellaneda, 2006). First is the conflict school which argues that democracy hampers economic growth, mainly in developing countries, by creating consumption pressures, fuelling distributional conflicts and inhibiting capital accumulation; second is the compatibility school that posits that democracy enhances economic growth, because the existence of fundamental liberties, political rights and institutional structures generate the social conditions that are conducive to economic development; and lastly is the skeptical school that maintains that there is no systematic linkage between democracy and economic development (Eregha, 2014).

In the light of the fact that institutions investment policies are mutually reinforcing and both affects economic growth outcomes, this study becomes imperative.

Against this background, the following research questions are pertinent to this study:

(i) What is the link between institutions, foreign direct investment and economic growth in Nigeria?

(ii) Does democratic institutions and foreign direct investment significantly affect growth in Nigeria?

\section{Review Of Literature}

\subsection{Democracy and Economic growth}

Sorensen (1993), cited in Ayanwu and Erhijakpo, (2014) defines democracy as political arrangements, participation, institutions and processes that guarantee the rights and freedoms to choose and replace leaders through regular and free elections, equality of opportunity and access, and a just distribution of social benefits and burdens to all. Democracy encompasses political freedom in elections, transparency of the government and political participation and civil liberties (freedom of speech, union rights and rule of law). The rule of law is upheld by an independent and fearless judiciary. Leading to a situation where citizens have political and legal equality (equality before the law), state officials are themselves subject to the law, and individual and group liberties are respected as enshrined in the constitution. People are free to organize, demonstrate, publish, petition, and air their opinion on social and political issues. Print and electronic media are free to report and comment, and to expose wrongdoing, without fear, intimidation, harassment, proscription or outright closure (freedom of the press). Minority groups can practice their culture, faith, and beliefs without fear of victimization and harassment. There is check and balances. Property rights are protected by law and by the courts. In addition, corruption is punished and 
deterred by autonomous, effective means of monitoring and enforcement (Diamond, 1999, cited in Ayanwu and Erhijakpo, 2014). Strong democratic institutions which facilitate good governance and enhance capital accumulation and investment are imperative for sustained growth (Avellaneda, 2006). Acemoglu, et al. (2002) has shown that weak democratic and institutional structures largely explain the low level of economic performance in developing countries and the differential rates of growth among countries. In the light of this, countries that have experienced rapid and sustained economic growth are those with sound institutional framework, stable macroeconomic policies that sufficiently attracts investment, technological innovation, and international economic integration (Helpman 2004; Avellaneda, 2006).

\subsection{Democracy, Foreign Direct investment and Economic Performance-The Nexus}

Economic performance refers to the overall level of economic progress or advancement in all sectors of an economy, in terms of volume and value of output, level of employment, factor productivity and the level of other economic activities, and how these translate into improved welfare for the citizens. According to World Bank (2002, cited in Aigheyisi, 2014), per capita income is one of the most significant measures of economic performance, and the gross domestic product (GDP) is the most commonly used measure of a country's economic activities. Thus, growth rate in GDP measures the level of economic growth. However, it has been argued that impressive income or GDP does not always translate into improved welfare, hence several researchers and analysts have questioned the validity of income as a measure of economic performance. Some researchers have suggested the human development index (HDI) as a more appropriate and holistic measure of economic performance measure of welfare, encompassing not just income, but also longevity, knowledge and other critical life-sustaining indicators.

It can be inferred from the foregoing, that there is no generally accepted single measure of economic performance, as each of the aforementioned measures (GDP, real GDP or the growth rate of real GDP, and $\mathrm{HDI}$ ) are frequently used in empirical researches as proxy for economic performance. A strong mutual relationship exists between economic growth, foreign investment and democracy. While improved economic performance depends on sound democratic structures and institutions reflected in the rule of law, effectiveness and predictability of the judiciary, enforceability of contracts proceedings, and secure property rights which enhance foreign investment needed to accelerate economic growth, a strong and virile economy reflected in positive macroeconomic performance is a key determines foreign investment (Acemoglu et al 2002).

Thus, democracy in the context of good governance and democratic institution enhances economic growth and alternatively, foreign investment is stimulated by good democratic structure, particularly with respect to the rule of law, enforceability of contracts, secure property rights and robust macroeconomic performance reflected in impressive growth rates.

\subsection{Trend of Foreign Direct Investment in Nigeria}

Nigeria is regarded as the largest and most attractive market in Africa given her large population of over 170 million and its economic size (measured by GDP). Its GDP at current price of $\$ 521.8$ billion is the largest in Africa. FDI inflow to West Africa is mainly dominated by inflow to Nigeria which received $70 \%$ of the sub-regional total and $11 \%$ of Africa's total FDI with $90 \%$ of the FDI inflow going to Nigeria's oil sector (UNCTAD, 2006). Official data by the World Bank (2014) show that net FDI inflows into Nigeria were $-\$ 738$ million in 1980 . It increased sharply to $\$ 542$ million in 1981 and fell to $\$ 189$ million in 1984 . Between 1985 and 1988, there were fluctuations in FDI inflows. In 1989, FDI increased sharply to $\$ 1.9$ billion, declining to $\$ 712$ million in 1991 , and improving again in 1992 to $\$ 897$ million. This increasing trend continued and peaked at $\$ 1.6$ billion in 1996. 
Although FDI inflows to Nigeria fluctuated slightly between 1997 and 2000, there was a consistent increase in 2001, 2002 and 2003 as FDI rose to $\$ 1.2$ billion, $\$ 1.9$ billion and $\$ 2$ billion respectively. Except for the slight reduction in 2004, Nigeria experienced a remarkable improvement in FDI inflows between 2005 and 2009 as it recorded $\$ 4.9$ billion in 2005, $\$ 4.6$ billion in 2006, $\$ 6$ billion in 2007, $\$ 82$ million in 2008 and $\$ 85.5$ million in 2009. In $2010 \mathrm{FDI}$ inflows dropped to $\$ 6$ billion, rebounded to $\$ 8.8$ million in 2011 and further declined to $\$ 5.6$ billion in 2013.

Data from the Nigerian Economic Report (2013) show that GDP growth rate was 6.5\% in $2005,6.0 \%$ in $2006,6.5 \%$ in $2007,5.98 \%$ in $2008,6.96 \%$ in $2009,7.98 \%$ in $2010,7.43 \%$ in $2011,6.68 \%$ in 2012 and $6.2 \%$ in 2013. The improvement in GDP growth rate can undeniably be attributed to a robust non-oil export growth rate of $26 \%$ in 2006 and $27 \%$ in 2007 , accompanied by a non-oil GDP growth rate of $8.95 \%$ in $2008,8.3 \%$ in $2009,8.49 \%$ in $2010,8.8 \%$ in 2011, 7.89 in 2012 and $6.3 \%$ in 2013. Correspondingly, FDI growth rate was $163 \%$ and $172 \%$ in 2005 and 2006 respectively (CBN, 2007). However, beginning from 2005, Nigeria started experiencing decline in FDI. The dwindling FDI inflows in recent times, has become a subject of concern. The decline has been attributed to a number factors among which are poor macroeconomic policy environment, political instability, security concerns, poor bureaucratic processes, weak infrastructure and institutional framework and a pervasive rent-seeking behaviour (UNCTAD, 2015).

\subsection{Empirical Review}

Lim (2001) examines the link between determinants of FDI and economic growth. The empirical results show that a combination of political, democratic variables and FDI determines growth. The findings also show that political and institutional variables were significant determinants of FDI.

Bengoa and Sanchez-Robles (2003) findings also corroborated earlier results that institutions are critical determinants of FDI and growth and that FDI impacts more on growth in when accompanied by good institutional structures like rule of law, bureaucratic procedures, control of corruption, accountability, e.t.c.

Jensen (2003) examines the relationship between democratic governance, FDI and economic growth using evidence from ten African countries. Employing various econometric tools, including the Granger causality test, his findings reveal a negative and significant link between weak democratic governance structures and FDI on one hand, and a positive and significant relationship between democratic governance, FDI and growth.

Sung (2004) investigates the nexus between state failure, economic failure and predatory organized crimes in a total of 59 countries covered in the 1999 and 2000 annual economic competitiveness evaluations conducted by researchers at Harvard University and the World Economic Forum. Employing the least-squares dummy variable model, the findings of the bivariate model show that weak state capacity and institutional framework leads to slower economic development. Empirical result from the multivariate model also showed that judicial independence has a negative correlation with organized crime. However, when judicial independence and institutional stability were held constant, the expansion of political rights facilitated the growth of predatory organized crime. This unexpected result according to the study indicates that state failure is a multidimensional variable and, as such, maintains a complex relationship with predatory organized crime. He thus, recommended strong institutional framework in order to enhance economic performance.

Yuan and Khan (2004) construct a dynamic model of a kleptocratic dictatorship to explain Sub-Saharan Africa's (SSA) dismal economic performance between the early 1970s and the mid-1990s. The dictator's objective is to maximize a discounted stream of revenue generated through theft of the economy's output by choosing the optimal expropriation rate and the size of the security force employed to enforce his rule. The model is used to evaluate alternative intervention options open to developed countries such as unconditional, 
conditional and selective foreign aid, financial and military assistance to rebel groups, as well as medical relief to combat the HIV/AIDs pandemic. The findings show that kleptocratic dictatorship has a significant destabilizing effect on SSA's growth through expropriation and its distorting influences via channels of physical and human capital accumulation.

Chauvet, Collier and Hoeffler (2007), cited in Elijah and Ayodele, 2013) estimate the cost of state institutional failure and weak capacity on economic growth, both for the failing state itself and for its neighbours covering a global sample of developing countries over the period 1974-2001. Employing the Ordinary Least Squares (OLS) and the Generalized Method of Moment (GMM) as techniques for estimations, the empirical results revealed that a failing state at peace significantly reduces the growth rate by 2.6 per cent relative to being at peace with adequate policies and governance, while violence and crimes induces a further loss of 1.6 percent of growth per year.

Knutsen (2010) investigates the impact of democracy and dictatorship on economic growth in Sub-Saharan Africa, and whether the effect of democracy on growth depends on level of state capacity and institutional structures. Importantly, the, the study focused on the adverse economic effects of dictatorial regimes in countries with weak state institutions. In such context, leaders pursue policies that are macro economically inefficient, but which enhance their survival in office and increase their personal wealth. The empirical analysis shows that democracy most likely contributes to higher growth rates in Sub-Saharan Africa, and that democracy has a larger positive effect on growth in Africa than globally. Moreover, the empirical findings using African and global evidences show that democracy has a particularly positive effect in countries with weak state institutions. The interaction between weak state capacity and dictatorship is found to be a vital factor underlying Africa's many economic development disasters. Against the background of these empirical findings, the author suggests the building of strong institutions, particularly state capacity to enhance growth in Africa.

Nurt-tegin and Czap (2012) employs the ordinary least squares estimation technique to investigate the relationship between stable democracy and economic growth, and unstable democracy and economic growth in selected countries in the period $2000-2009$. The findings reveal that less democratic societies are likely to experience less growth than stable democratic regimes.

Ogundiya (2010) investigates the impact of corruption on democratic stability. The author finds that political corruption and bureaucratic corruption have significant effects on democratic stability. This according to the findings may have destabilizing effects on growth. Ernest and Young (2013) have shown that a country's institutional framework is a critical determinant of FDI and, that institutional structures and FDI are positive and significant determinants of growth. According to the findings, issues like rule of law, control of corruption and bureaucratic procedures are considered critical determinants of FDI and economic growth

Eregha (2014) empirically investigates the impact of weak institutions and governance on economic performance in ECOWAS countries. Employing panel data analysis, the findings show that accountability is a sin-quo-non for increased per capita GDP growth in the region. The results further show that the channel through which institution affects growth is investment. Weak institutional framework and poor governance is found to account for the low per capita GDP growth in the region. Consequently, the author recommended that strengthening the region's institutions and offering good governance system will put the region on the path of growth and development. 


\section{Empirical Methodology \\ 3.1 Model Specification \\ Growth Equation}

In line with Mankiw, Romer and Weil (1992), a growth model which is an extension of the Solow (1956) neoclassical growth model augmented with investment is specified. One important assumption in this specification is that institutions are considered to affect growth through two main channels: the total factor productivity and the investment channels. To investigate the effect of democracy and foreign direct investment on economic growth a stylized growth-cum institutions and foreign direct investment model of the form:

$$
\Delta y_{t}=a_{0}+a_{1} x_{i}+u t
$$

Where:

$\Delta y t=$ growth of income- a proxy for economic growth;

$X_{i}=$ an index of democratic institutional development variables, foreign direct investment and other control variables such as state effectiveness

Extending equation (1) in its empirical form, the model is specified as:

RGDPG $=\alpha_{0}+\alpha_{1}$ FDI $+\alpha_{2}$ RULE $+\alpha_{3}$ ACCOUNT $+\alpha_{4}$ POL $+\alpha_{5}$ GOVEFF $+\alpha_{6}$ CORRUPT + $\mu \ldots . .(2)$

Where RGDPG = Growth Rate of Real Gross Domestic Product (a measure of economic performance);

$\mathrm{FDI}=$ foreign direct investment

RULE = rule of law;

Account=accountability;

POL=political stability;

GOVEFF=government effectiveness;

$\mathrm{REGQ}=$ regulatory quality;

CORRUPT $=$ Control of corruption and $\varepsilon=$ stochastic error term.

$\alpha_{1}-\alpha_{6}$, are parameters or coefficients of the explanatory variables to be estimated.

The rule of law (Rule of Law) includes several measure of the degree of confidence of the citizenry in accordance with the laws and rules of society. These include perceptions of the incidence of crime, the effectiveness and predictability of the judiciary, and the enforceability of contracts proceedings. Accountability measures the ability of a country's citizens and political office holders to be accountable and responsible to the government in terms of actions and policies. The Rule of law is based on a number of indicators measuring supremacy of the law, equality before the law, civil liberties and human rights. Political Stability measures the stability of the political system (political stability) and absence of violence which measures the likelihood that the government in power will be destabilized or overthrown by unconstitutional means and or violence or threatened by the armed conflict such as terrorism. Government effectiveness measures quality and availability of public service, the bureaucracy, the competence of civil servants, the independence of the administration of political pressure and the credibility and transparency of the government's reform commitments and policies. Control of corruption measures the extent of corruption, defined as the use of public power for personal interests, private profit and personal aggrandizement in terms of wealth and illegal resource appropriation. It includes government commitment and transparency to fighting corruption and the extent to which those found culpable are brought to face the law. 


\subsection{Data Sources and Estimation Technique}

The data used for the study are annual time series data covering the period 1981-2015 and were obtained from various sources to include, World Bank World Development Indicators and Central Bank of Nigeria Statistical Bulletin. The study employs the Generalized Method of Moments (GMM) approach in the estimation of the model in order to overcome the problem of joint endogeneity in the estimation and, thus to control for the biases resulting from simultaneous or reverse causation. All data are in log form.

\section{Empirical Analysis}

\section{Table 1: Results from Generalized Method of Moments (GMM) Dependent Variable: RGDP}

\begin{tabular}{|l|c|c|}
\hline Variables & Estimated Coefficient & t-statistics \\
\hline C & 0.2114 & 1.4015 \\
\hline LnFDI & 0.1125 & $3.1724^{* * *}$ \\
\hline LnRULE & -0.1014 & $-2.104^{* *}$ \\
\hline LnACCOUNT & -0.0196 & $-1.7912^{*}$ \\
\hline LnPOL & -0.0871 & -1.4217 \\
\hline LnGOVEFF & 0.2213 & $2.1233^{* *}$ \\
\hline LnCORRUPT & -0.2172 & $-1.7126^{*}$ \\
\hline
\end{tabular}

*** Statistical significance at the $1 \%$ leve

** Statistical significance at the $5 \%$ level

* Statistical significance at the $10 \%$ level

An examination of the results reported in Table 1 show that all variables have the correct signs. Since all the data are in log form, the coefficients are elasticities. The coefficient of FDI is positive in line with theoretical expectation and highly significant at the 1 percent level. This implies that increased foreign direct investment inflow will invariably steer economic growth in Nigeria, especially, through the introduction of productive capital, technological and managerial expertise through the channels of innovation, transfer of advanced technology and domestic capital accumulation. In particular, FDI through its positive spill-overs on human capital, technological innovation and managerial enterprise will induce growth in Nigeria (Teka, 2012). In line with the estimates, the elasticity of economic growth with respect to FDI is 0.11 . Thus, a 10 percent increase in FDI will on the average trigger economic growth in Nigeria by 1.1 percent. The coefficient of the rule of law (supremacy of the law and equality before the law) variable is negative and significant in influencing growth. This fact underscores the highhandedness of some political class and few privilege Nigerians regarded as ' untouchables or sacred cows' who violated the law in time past with so much impunity and abused public office without been held accountable. This implies that as public officers are held accountable to the law, only then will the rule of law in Nigeria be growth-inducing, otherwise it will hamper growth. The coefficient of accountability is negative and significant at the 10 percent level in affecting growth. This finding may be attributable to the lack of accountability and transparency that has dominated public service in Nigeria in the years past, and has had a destabilizing effect on growth. The findings thus imply that the more accountable or answerable government institutions to the public in their policies, actions and spending, the more economic growth would be enhanced Accountability should therefore be accounted for in investment, government expenditure and policies in order to bring the much needed growth. The elasticity coefficients show that a 10 percent rise in weak democratic institutions of rule of law and accountability will hamper growth by 1.0 percent and 0.2 percent, respectively. The coefficient of political stability is negatively 
signed (though insignificant). This implies that rising political instability has a destabilizing impact on growth, although the impact is weak, particularly in the face of effective state capacity, which may reduce the destabilizing effects on growth. It can therefore be deduced sustained economic growth cannot take place in an atmosphere of political and economic instability, but only when the environment is stable and institutions are right. Accordingly, its elasticity coefficient shows that a 10 percent rise in political instability will reduce economic growth in Nigeria by 0.9 percent approximately. The coefficient of government effectiveness is negatively signed and significant at the 5 percent level. This implies that the quality and availability of public service, the bureaucracy, the competence of civil servants, the independence of the administration of political pressure and the credibility and transparency of the government's reform commitments and policies have negatively affected growth in Nigeria. Thus, a greater level of government effectiveness in terms of quality and availability of public service, public bureaucracy, competence of civil servants, the independence of the judiciary, effective administration, absence of undue political pressure and credibility and transparency of the government's reform commitments and policies are imperative to significantly drive economic growth in Nigeria. The control of corruption variable is negatively signed and significant at the 10 percent level. Invariably, corruption has a destabilizing impact on growth in Nigeria, since it crowds out resources meant for growth, weakens the productive system and discourages the incentive to invest. The intuition of this finding is that the fight against corruption in Nigeria is yet to yield significant positive effects on the economy, as corruption has been endemic over the years. Thus, it should be vigorously continued. In particular, it should be relentlessly pursued with greater vigour devoid of political colouration and sacred cows, if it must yield the desired positive effects on growth. The elasticity coefficient of corruption shows that a 10 percent rise in corruption will decelerate economic growth by 2.2 percent.

\section{Conclusion}

This study has examined the effect of democratic institutions and foreign direct investment on real GDP growth in Nigeria over the period 1981-2015, using GMM estimation approach. The empirical findings revealed that democratic institutions and foreign direct investment are critical variables that influence economic growth in Nigeria. In particular, the empirical findings show that the FDI, rule of law, accountability, government effectiveness and control of corruption affect growth in Nigeria. This was shown by the negative and significant coefficients of rule of law, accountability, government effectiveness and corruption, which combine to undermine growth. The effect of political instability and control of corruption variables were found to hamper growth, an indication that the fight against corruption in the Nigeria must be holistic and transparent in order to have the desired positive effect on growth. Similarly, a stable political environment devoid of uncertainty and conducive to foreign direct investment inflow and growth must be created. Consequently, government needs to strengthen the institutional framework in order to provide the needed enviroment for rapid economic growth. The combination of strong democratic institutions embedded in the rule of law, effectiveness and predictability of the judiciary, enforceability of contracts, secured property rights, strong bureaucratic institutions, control of corruption and, importantly, sound macroeconomic policy environment that enhances foreign direct investment will help to steer the economy towards the path of sustained economic growth.

\section{References}

Acemoglu, D., S. Johnson and Robinson, J.A. (2002). 'Reversal of Fortune: Geography and Institutions in the Making of the Modern World income Distribution', Quarterly Journal of Economics, vol. 117, no.4, pp. 1231-1294. 
Adelagan, O.J., and Olabisi, N. (2013). 'Impact of Democracy on Foreign Direct Investment and Economic Growth in Nigeria', Journal of Development Initiative, vol. 4, No. 8, pp, 120-128.

Aigheyisi, O. S. (2013). 'Corruption, Government Expenditures and Economic Performance: Nigeria's Experience in the Democratic Era', Paper Presented at the $54^{\text {th }}$ Annual Economic Conference of the Nigerian Economic Society (NES), Abuja, Nigeria, September, 17-19.

Avellaneda, S.D. (2006). 'Good Governance, Institutions and Economic Development: Beyond the Conventional Wisdom. Paper Presented at the Forum de Recerca, Departament de Ciencies Politiques Socials, Universitat PompeuFabra, Barcelona 3 de Mayo 2006.

Ayanwu, J.C. and Erhijakpor, J.E.O. (2014). 'Oil wealth and Democracy in Africa: Cross-country Evidence and Lessons for Africa', Paper presented at the $54^{\text {th }}$ Annual Economic Conference of the Nigerian Economic Society (NES), Abuja, Nigeria, September, 17-19.

Barro, R. (1998). 'Determinants of Economic Growth: A Cross-Country Empirical Study', Cambridge: The MIT Press.

Bengoa, M. and Sanchez-Robles.B. (2003). 'Foreign Direct Investment, Economic Freedom and Growth: New evidence from Latin America', European Journal of Political Economy, vol. 19, pp. 529-545.

CBN (2007). CBN Statistical Bulletin, Abuja: Central Bank of Nigeria Press.

Chauvet, L., P. Collier and A. Hoeffler (2007). 'The Cost of Failing States and the Limits to Sovereignty', World Institute for Development Economics Research Paper No. 2007/30.

Diamond, L. (1999).'Developing Democracy: Towards Consolidation', Baltimore, Johns Hopkins University Press, 10-12.

Diop, A., G. Dufrenot and Sanon, G. (2010). 'Is per capita growth in Africa hampered by poor governance and weak Institutions? An empirical study on the ECOWAS Countries', African Development Review, vol. 22, no.2, pp.265-275.

Drazen, A. (2000). Political Economy in Macroeconomics, Princeton University Press.

Easterly, W. and Levine, R. (2002). It's not factor accumulation: stylized facts and growth models. Working Papers Central Bank of Chile 164, Central Bank of Chile.

Elijah, U. and Ayodele, O. (2013). 'State Failure, Capital Flight and Economic Growth: An Econometric study of Nigeria', Paper Presented at the $54^{\text {th }}$ Annual Economic Conference of the Nigerian Economic Society (NES), Abuja, Nigeria, September, 17-19.

Eregha, P.B. (2014). 'Is Per Capita Growth Hampered by Weak Institutions and Poor Governance in ECOWAS Countries? A Panel Data Analysis', Paper Presented at the $54^{\text {th }}$ Annual Economic Conference of the Nigerian Economic Society (NES), Abuja, Nigeria, September, 17-19.

Ernest and Young, (2014). 'Executing Growth. 'EY's Attractiveness Survey', Africa 2014.

Fosu, A., Bates, R., and Hoeffler, A. (2006). 'Institutions, Governance and Economic Development in Africa: An overview', Journal of African Economies, Vol. 15, No. 1, Pp 1-9. Helpman, E. (2004). 'The Mystery of Economic Growth' Cambridge, MA: Harvard University Press.

Jensen, N.M. (2003). Democratic governance and multinational corporations: political regimes and inflow of foreign direct investment. International Organization 57 Summer 2003, 587-616.

Kaufmann, D. and Kraay, A. (2003). 'Growth without Governance', Economia: The Journal of the Latin American and Caribbean Economic Association, vol. 3, no.1, pp. 169-215.

Knack, S. (Ed.) (2003). 'Democracy, Governance and Growth, Ann Arbor', The University of Michigan Press.

Knutsen, C. H. (2010). Africa's Growth Tragedy Revisited: Weak States, Strong Rulers', Paper Presented at the Centre for the Study of Civil War's Working Group meeting on October 15-16, Department of Political Science, University of Oslo. 
Lim, E.(2001). 'Determinants of and the Relation between Foreign Direct Investment and Growth: A Summary of Recent Literature', IMF Working Paper, WP/01/175.

Mankiw, N. G., Romer, D., and D. N. Weil, (1992).'A Contribution to the Empirics of Economic Growth. Quarterly Journal of Economics, vol 107, pp.407-437.

Nigeria Economic Report (2013).World Bank.

Nurt-tegin, K. and Czap, H. J. (2012). 'Corruption, Democracy, Autocracy and Political Stability', Economic Analysis and Policy, vol. 42, no. 1, pp., 51 - 66.

Ogundiya, I. S. (2010). Corruption: 'The Bane of Democratic Stability in Nigeria', Current Research Journal of Social Sciences. vol.2, no. 4, pp. 233-241. Avaiable from http://maxwellsci.com/print/criss/v2-233-241.pdf, [17 August 2013].

Rodrik, D., Subramanian, A. and Trebbi, F. (2004). 'Institutions Rule: The Primacy of Institutions over Geography and Integration in Economic Development', Journal of Economic Growth, vol. 9, no.2, pp. 131-165.

Solow, R. M. (1956). 'A Contribution to Theory of Economics Growth', The Quarterly Journal of Economics, vol. 70, no.1, pp. 65-94.

Sung, H. (2004). State Failure, Economic Failure, and Predatory Organized Crime: A Comparative Analysis', Journal of Research in Crime and Delinquency, vol. 41, no. 2, pp. 111-129.

Teka, C. (2012). 'Foreign Direct Investment and Economic Growth', European Journal of Economics and Finance, vol. 4, no. 6, pp. 60-78.

UNCTAD (2006 and 2015). World Investment Report

World Bank (2014).World Development Report 2015. Washington D.C : World Bank.

Yuan, K.C. and Khan, H. (2004). 'Explaining Africa's Growth Tragedy: A Theoretical Model of Dictatorship and Kleptocracy', The University of Melbourne Department of Economics Research Paper 922, pp. 1-40.

\section{Bio-note}

Hassan Ozekhome holds a B.Sc (Hons) (Economics and Statistics) and M.Sc degree (Economics), of the University of Benin, Benin City, Nigeria. He has completed the PhD course work in economics in the same University, and is at the final stage of his Doctoral Dissertation. His main research interest is in Macroeconomics, Development economics, International economics and Monetary economics, with special interest in Applied econometrics. He has published widely in both local and reputable international journals. 